\title{
Erratum to: Chinese Capitalism in Southeast Asia
}

\author{
Yos Santasombat
}

\section{Erratum to:}

Y. Santasombat (ed.), Chinese Capitalism in Southeast Asia, DOI 10.1007/978-981-10-4696-4

In the original version of the book, in Chapters 1 and 7 , the author name needed to be changed from "L.K. Cheng" to "K.C. Lee" in chapter opening pages and running heads and the incorrect institutional affiliation "Sociology and Anthropology Department Faculty of Social Sciences" needed to be corrected to read as "School of International Affairs, Faculty of Political Science and Public Administration". The erratum book has been updated with the changes.

The updated original online version for this book can be found at DOI 10.1007/978-981-10-4696-4 